\title{
TUMBUH KEMBANG NILAI-N ILAI KEISLAMAN DI KALANGAN SISWA-SISWI SMA DI SURABAYA UTARA
}

\author{
Hartono*
}

\begin{abstract}
Thispeperdisassesthehighly controversial issuesinthenothem part of Surabeya; an issuethat has attracted theattention of both parents and teaches alike, theissue of High School studants' attachment to the values of Idam Many womied that given ther attitude, thesestudentshaveno conem whatsoever with thebasicpiniples of Isam Thispeper will show the othervise by invetigating carefully thenotion of career dhiceammg these students. This speific fidd of investigation has not reeived proportional attention fromany fied rearcher apart fromitssigificanceboth to the state of ar education andmoral conduct. Thepaper first argues that theattitude of thesestudantsis morecomplicated than many haveassumed It then triestoshouthat reigious valuesareinfact thestrongest deteminantsinstudants making their career dhice This thery comes as a serias dallenge to many basdess assumptions that as a religion Idamhas lost itsinflueneouer its younger followes This rearch is donein diffeent areasin thenothem part of Surabaya. Thequestionnairesaredistributed at randomrepresentingeach aree proportionally. The data are clleeted through thesequestionnaires based on the thery of Hdland RIASEC.
\end{abstract}

Keywords: Isamicvalues, career dhice

\section{Pendahuluan}

Islam adalah agama besar yang diturunkan Allah melalui para rasulnya. Islam kaya dengan nilai-nilai penuntun hidup yang wajib dilakukan oleh pemeluknya (komunitas muslim) dalam kehidupan bermasyarakat, berbangsa, dan bernegara. Nilai-nilai (values) Islam adalah suatu keyakinan mengenai cara bertingkah laku dan tujuan akhir yang diinginkan individu, yang digunakan sebagai prinsip atau standar dalam hidupnya yang bersumber dari al-Q ur'an dan al-Hadis. Nilai-nilai Islam yang diyakini kebenarannya membentuk, mengarahkan, dan menguatkan sikap dan perilaku individu dalam melakukan pilihan karier (career dhice) sebagai aspek penting dalam kehidupannya.

Siswa SMA pemeluk agama Islam merupakan komunitas muslim yang berada dalam periode realistik ${ }^{1}$ dan periode eksplorasi. ${ }^{2}$ Pada periode realistik siswa mengalami pengintegrasian berbagai kapasitas dengan minatnya yang terfokus pada pilihan karier (career dhice), sedangkan pada periode eksplorasi, siswa menghadapi dinamika pada berbagai pilihan, terutama pilihan yang didasarkan kebutuhannya untuk memikirkan secara serius kemungkinan memasuki bidang karier tertentu. Pada periode ini siswa seharusnya mampu membuat perencanaan karier yang terkait dengan masa depannya. Bila gagal akan berdampak buruk terhadap perkembangan kariernya, sedangkan bila berhasil akan menunjang tugastugas perkembangan kariernya. D engan demikian pengintegrasian potensi diri siswa SMA pemeluk agama islam (minat, kemampuan, dan karakteristik kepribadian) yang terfokus

*Fakultas Keguruan dan Ilmu Pendidikan (FKIP) Universitas PG RI Adi Buana, Surabaya.

${ }^{1}$ Vernon G. Z unker, CarerCansding A ppliedConeqtsof LifePlanning SixthEdition(United Kingdom: Brooks/ Cole., 2002), 35.

${ }^{2}$ Richard S. Sharf, Applying Career D evelopment Theory to Counseling, Third E dition (Australia: Brooks/ Cole., 2002), 158. 
pada pemilihan karier, harus dilakukan secara bersungguh-sungguh, dengan mempertimbangkan dinamika yang terjadi akibat modernisasi berdasarkan nilai-nilai Islam sebagai aqidah dan menjadikan aqidah Islamiyah sebagai standar hidupnya.

Karier adalah bagian dari kehidupan orang dewasa, yang penyiapannya dilakukan melalui perencanaan karier sejak dini, dikenalkan sejak pendidikan prasekolah yang berlangsung melalui pendidikan dasar dan menengah, menuju kejenjang pendidikan tinggi. Padajenjang pendidikan dasar dan menengah khususnya masa SMA, peristiwa pemilihan karier menjadikan hal yang sangat penting dimana para siswa melakukan berbagai upaya belajar sesuai minat, kemamampuan dan karakteristik kepribadiannya untuk memilih bidang karier berdasarkan nilai-nilai yang diyakininya. ${ }^{3}$ Pada jenjang pendidikan tinggi, mereka merebut suatu karier yang telah dipilihnya sejak di SMA, dan mempertahankannya dalam kehidupan di masyarakat.

Islam mengajarkan bahwa pendidikan dan belajar adalah bagian dari iman, tujuannya menyempurnakan ubudiyah kepada Allah subhanahu wata'ala (ibadah), yang berasaskan kemaslahatan bagi umat dan kemanusiaan. ${ }^{4}$ Pelajar yang memiliki motivasi keagamaan dan karier dalam belajar akan mempunyai kreativitas dan etos kerja yang baik, sebab mereka bekerja dengan semangat yang didasarkan atas keyakinan dasar agama. Bidang karier yang mereka geluti di masa mendatang akan diposisikan sebagai bagian dari pengabdiannya kepada Allah, bahkan mereka melihat karier dan pengabdian dalam kerangka pikir yang lebih luas, yakni untuk kemajuan Islam, umat Islam dan kemanusiaan.

Nilai-nilai yang diyakini individu mempengaruhi perilakunya melalui proses interaksi yang berlangsung secara terus menerus di dalam kehidupannya ${ }^{5}$ D engan kata lain, nilai-nilai Islam dapat mempengaruhi perilaku seseorang melalui proses belajar. Secara psikologis, belajar merupakan proses perubahan perilaku yang terjadi di dalam diri seseorang secara disadari. Melalui belajar, seseorang bisa memperoleh pengalaman-pengalaman baru yang sangat bermanfaat di dalam kehidupannya. Tak terkecuali, pengalaman dalam melakukan pemilihan karier, yang diidentifikasikan sebagai suatu momen yang sangat penting. ${ }^{6}$ O zbilgin, Kusku, dan Erdogmus menyatakan bahwa pemilihan karier sebagai peristiwayang kompleks, sehingga masalah ini sebagai fokus banyak studi yang dilakukan oleh para ahli psikologi, antropologi, dan sosiologi.7

Triandis menyimpulkan bahwa nilai-nilai ditanamkan (giving) dari generasi ke generasi berikutnya. ${ }^{8}$ Nilai-nilai Islam ditanamkan oleh orang-tua dan guru kepada anak-anaknya atau anak didiknya sebagai sesuatu hal yang penting dalam kehidupannya. Nilai-nilai Islam diperankan sebagai sumber peradaban umat muslim yang berlangsung dari zaman ke zaman. Nilai-nilai Islam mempengaruhi proses pemilihan karier seseorang siswa melalui proses

\footnotetext{
${ }^{3}$ M.J. Miller \& T.A. Miller, "Theoretical Application of Holland's Theory to Individual D ecision-Making Styles: Implications for Career Counselors", dalam Jaumal of Employment Caunsding(American Counseling Association, 2005) $42,1,20-28$.

${ }^{4}$ Admin, Implerentas Nilai-Nilai IdamdalamDuniaPendidikan(2010), 2. Tersedia di http:/ / www.wahdah-tarakan.org. ${ }^{5}$ John W. Berry; Y pe H. Poortinga; Marshall H. Seegal; Pierre R. D osen, CrossCultural Psychogy: Reerchand Applications (Canada: Cambridge University Press., 1992), 32.

${ }^{6} \mathrm{~J}$.E. Myburgh, "An E mpirical Analysis of Career Choice Factors that Influence first-year Accounting Students at the University of Pretoria: A Cross-racial Study", dalam Journal of MeeitaryAcauntangRRerch(2005) 13, 35-48. ${ }^{7}$ M. O zbilgin; F. Kusku; N. Erdogmus, Explaining Influences on Career Choice in Comparative Perspective: International Programs Visiting Fellow Working papers (2004), 1. Tersedia di http:/ / digitalcommons.ilr.cornell.edu/ intlvf/ 1.

${ }^{8}$ Harry C. Triandis, Cultureand Social Bdhavior(New York: McGraw-Hill, Inc., 1994), 92.
} 
internalisasi yang berlangsung di dalam diri individu yang ditanamkan oleh orang-tua, guru, dan atas pengaruh masyarakat komunitas muslim.

Manusia adalah makhluk sosial yang berimplikasi pada sikap dan perilakunya di dalam lingkungan keluarga, sekolah dan masyarakat. Di sekolah siswa melakukan proses interaksi terstruktur yang bertujuan untuk mencapai derajat kompetensi ilmu pengatahuan dan teknologi yang diamanatkan oleh kurikulum. Di dalam komunitas sekolah-sekolah muslim, para siswa melakukan interaksi dengan guru, staf sekolah, dan teman sebaya (per gaup) sebagai wahana dalam penerimaan nilai-nilai keislaman. Nilai-nilai ini akan menentukan sikap dan perilakunya dalam melakukan pemilihan karier (career dhice) yang menentukan masa depannya. ${ }^{9}$

Menurut teori Holland pilihan karier merupakan ekspresi karakteristik kepribadian seseorang ke dalam dunia kerja yang disebut RIASEC (realistic, inestiggtive, artistic eterpising dan conventional). Bidang karier realistik (realistid mencakup beberapa aktivitas kerja seperti bangunan, mekanik, operator mesin, dan reparasi. Seseorang yang berminat pada bidang ini cenderung menyukai aktivitas kerja di ruang terbuka. Beberapa pekerjaan dalam bidang realistik meliputi pertanian, pekerja pabrik, polisi, militer/ tentara, insinyur, atletik, berdagang, rimbawan, dan reparasi. Bidang karier investigatif (inesigative), mencakup beberapaa aktivitas kerja seperti aktivitas mengumpulkan data, melaksanakan penelitian, mengorganisir material untuk analisis data-data penelitian. Beberapa pekerjaan yang termasuk bidang ini adalah peneliti, ahli matematika, ilmuwan, ahli audio, profesor, apoteker, dokter gigi, peternakan, dan ahli kacamata. Artistik (artistid adalah bidang karier yang bercirikan nilai-nilai keindahan dan peminatnya cenderung melakukan ekspresi diri. Aktivitas kerja ini mencakup; menulis/mengarang, mendekorasi, dan merancang dengan suasana kebebasan. Lingkungan kerja ini, meliputi musium, teater, galeri, dan konser. Contoh pekerjaan ini yaitu artis, pendekorasi, arsitektur, fotografer, ahli musium, ahli studio televisi, desain interior, dan pengiklanan.

Sosial (soial) adalah bidang karier yang berhubungan dengan pelayanan kepada manusia dan memperhatikan kesejahteraan umat manusia. Bentuk aktivitas ini seperti memberi informasi, mengajar, melatih, melayani, mengelola, dan memimpin. Lingkungan kerja pada aspek ini mencakup agen pelayanan, pembimbingan agama, klinik kesehatan, perkantoran, dan fasilitas medis. Contoh kerja sosial yaitu: peredam konflik, guru/dosen, konselor, ahli pengobatan, psikolog, perawat, dokter, pekerja sosial, dan pembina kenakalan remaja. Enterprising adalah bidang karier yang membutuhkan daya saing yang kuat dalam melihat peluang. Bentuk aktivitas ini mencakup menjual, mengelola, pidato, dan memimpin kelompok orang. Lingkungan kerja ini meliputi: agen penjualan, investasi pada perusahaan perbankan, perdagangan eceran, perdagangan grosir, dan bisnis secara otonomi. Contoh pekerjaan: politikus, motivator, pimpinan perusahaan, pekerja sales, manajer kampanye, direktur humas, makelar saham, peragawan/ peragawati, dan konsultan industri. Konvensional (conetional) adalah suatu bidang karier yang aktivitas kerjanya memerlukan ketepatan dan ketelitian. Aktivitas konvensional mencakup pembukuan, penjadwalan, dan perusahaan pemeliharaan dan perawatan. Pilihan lingkungan kerja seperti perusahaan besar, perkantoran bisnis, dan perusahaan akuntansi. Contoh jenis pekerjaan meliputi pekerja kantor, pencatat pembukuan, petugas statistik, kasir bank, sekretaris, analis keuangan, manajer kantor, akuntan, dan petugas

${ }^{9}$ Mohamed Nimer, AnEduratar's GuidetoIdamicRdigiasPradices(Council on A merican-Islamic Relations, 2005), 6. Tersedia di http:/ / www.cair.com. 
administrasi bisnis.

Berdasarkan paparan di atas, dirumuskan permasalahan penelitian ini yaitu bagaimanakah pilihan karier siswa SMA dalam perspektif nilai-nilai Islam? Perspektif nilai-nilai Islam dibatasi sebagai sudut pandang seseorang berdasarkan nilai-nilai agama Islam. Penelitian ini bertujuan untuk mendeskripsikan pilihan karier siswa SMA dalam perspektif nilai-nilai Islam, dan perlu dilakukan untuk memperoleh nilai kemanfaatan bagi peneliti, guru bimbingan dan konseling, dan para siswa yang tengah menempuh pendidikan pada sekolah-sekolah berbasis agama Islam. Kemanfaatan bagi peneliti diwujudkan dalam bentuk perolehan pengalaman praktis dalam melakukan penelitian sebagai salah satu tugas peneliti sebagai pendidik. Kemanfaatan bagi guru bimbingan dan konseling diwujudkan dalam bentuk diperolehnyainformasi hasil penelitian ini yang diperlukan sebagai salah satu referensi dalam mengembangkan program pelayanan bimbingan karier di SMA yang merupakan bagian integral dalam keseluruhan program bimbingan dan konseling di sekolah. Sedangkan Kemanfaatan bagi para siswa SMA diwujudkan sebagai dampak langsung atas pelayanan bimbingan karier yang diberikan oleh guru bimbingan dan konseling kepada mereka berdasarkan hasil penelitian ini.

\section{Metode Penelitian}

Penelitian ini dikelompokkan sebagai penelitian deskriptif (desciptivererch desig) dengan populasi para siswa SMA kelas XI pada lembaga-lembaga pendidikan Islam di Surabaya. Sampel penelitian sebanyak 193 orang siswa diperoleh dengan menggunakan teknik area random sampling yang mewakili wilayah Surabaya utara, tengah, dan selatan. ${ }^{10} \mathrm{D}$ alam pengambilan sampel, pertamatama peneliti menentukan satu SMA berbasis Islam di wilayah Surabaya utara, satu SMA berbasis Islam di wilayah Surabaya tengah, dan satu SMA berbasis Islam di wilayah Surabaya Selatan dengan cara merandom lembaga pendidikan. Setelah diperoleh tiga SMA, kemudian dilakukan random subyek melalui cara undian. D engan menggunakan cara ini diperoleh sampel sebanyak 193 orang siswa. Rincian besarnya sampel penelitian diuraikan pada tabel 1.

D ata penelitian dikumpulkan dengan menggunakan kuesioner pilihan karier berdasarkan teori Holland RIASEC yang diadaptasikan dari NIU Career Servic ${ }^{11}$ yang dilakukan telaah ahli (expett revien) dan uji coba (try-ait) pada 30 responden di luar sampel penelitian yang memiliki karakteristik relatif sama dengan karakteristik sampel penelitian. Uji co ba dimaksudkan untuk memperoleh balikan dari responden dalam rangka menyerasikan penggunaan bahasa Indonesia yang bisa dimengerti oleh responden yaitu para siswa SMA kelas XI pada lembaga-lembaga pendidikan Islam. Kuesioner pilihan karier tersebut berisi 60 jenis pekerjaan yang dikelompokan ke dalam enam bidang karier yaitu Realistic Investigative, Artistic, Soial, Enteprising dan Conventional (RIASEC).

Bidang kanier realistik (relistid terdiri dari 10 jenis pekerjaan, yaitu pertanian, pekerja pabrik, polisi, militer/ tentara, atletik, berdagang, operator mesin, ahli teknik, rimbawan/ ahli kehutanan, dan reparasi. Bidangkarierinestigatif (ineetigative) terdiri dari 10 jenis pekerjaan, yaitu: peneliti, ahli matematika, ilmuwan, pemikir kritis, ahli audio, profesor, apoteker, dokter gigi, peternakan, dan ahli kacamata. Bidangkarier artistik (artistid terdiri dari 10 jenis pekerjaan,

${ }^{10}$ Meredith D. G all; Joyce P. G all; Walter R. Borg, Edurational Reserd: AnIntrodurtion(7 $7^{\text {th }}$ ed.) (New York: Pearson Education, Inc., 2003), 171.

${ }^{11}$ NIU Career Service, CareerInterestAress(2009), 1-2. Tersedia di http:/ / www.niu.edu/ careerservice. 
yaitu: penulis kreatif, pendekorasi, arsitektur, fotografer, teater/ drama, ahli musium, pengiklanan, ahli studio televisi, desainer interior, dan artistik. Bidang karier sosial (soaial) terdiri dari 10 jenis pekerjaan, yaitu: peredam konflik, pemimpin, pengelola, guru/dosen, ahli pengobatan, psikolog, perawat, konselor, pekerja sosial, dan dokter. Bidang karier enterpisingterdiri dari 10 jenis pekerjaan, yaitu: politikus, motivator, pemimpin bisnis, pekerja sales, manajer kampanye, direktur humas, makelar saham, peragawan/ peragawati, manajer kota, dan konsultan industri. Bidang kanier konvensional (conventional) terdiri dari 10 jenis pekerjaan, yaitu: perumus administrasi kantor, pekerja kantor, pencatat pembukuan, petugas statistik, kasir bank, sekretaris, analis keuangan, manajer kantor, akuntan, dan petugas administrasi bisnis.

Analisis data dilakukan dengan cara menghitung persentase setiap bidang karier (RIASEC) berdasarkan pilihan responden yang ditetapkan sebagai sampel penelitian, dengan menggunakan rumus $\mathrm{P}=\frac{\mathrm{f}}{\mathrm{N}} \times 100 \%$, dimana $\mathrm{P}$ adalah persentase, $\mathrm{f}$ adalah frekuensi, dan $\mathrm{N}$ adalah jumlah anggota sampel.

Tabel 1

\section{Sampel Penelitian Siswa Kelas XI SMA}

\begin{tabular}{ccccc}
\hline \multirow{2}{*}{ N o. } & \multirow{2}{*}{ Lokasi SMA } & \multicolumn{2}{c}{ Jenis kelamin siswa } & \multirow{2}{*}{ Total } \\
\cline { 2 - 4 } & & Laki-laki & Perempuan & \\
\hline 1. & Surabaya Utara & 33 & 31 & 64 \\
\hline 2. & Surabaya Tengah & 33 & 32 & 65 \\
\hline 3. & Surabaya Selatan & 34 & 30 & 64 \\
\hline & Jumlah & $\mathbf{1 0 0}$ & $\mathbf{9 3}$ & $\mathbf{1 9 3}$ \\
\hline
\end{tabular}

\section{Hasil Penelitian}

Pilihan karier responden penelitian sebagai sampel berdasarkan nilai-nilai Islam yang diyakininya pada enam bidang karier menurut teori John Holland, diuraikan pada tabel 2 sebagai berikut.

\section{Tabel 2}

Statistik Deskniptif Pilihan Karier Siswa Kelas XI SMA pada Lembaga-Lembaga Pendidikan Islam di Surabaya Berdasarkan Teori John Holland RIASEC

\begin{tabular}{clcc}
\hline No. & \multicolumn{1}{c}{ Bidang Karier } & $\begin{array}{c}\text { Frekuensi } \\
\text { (f) }\end{array}$ & $\begin{array}{c}\text { Persentase } \\
\text { (P) }\end{array}$ \\
\hline 1. & Realistic & 29 & 15,02 \\
\hline 2. & Investigative & 20 & 10,36 \\
\hline 3. & Artistic & 36 & 18,65 \\
\hline 4. & Social & 72 & 37,31 \\
\hline 5. & Enterprising & 12 & 6,22 \\
\hline 6. & Conventional & 24 & 12,44 \\
\hline \multicolumn{2}{r}{ Jumlah } & 193 & 100 \\
\hline
\end{tabular}


Berdasarkan tabel 2, responden yang memilih bidang karier realistik (realistid) sebanyak 29 orang siswa atau 15,02\%, responden yang memilih bidang karier investigatif (investigative) sebanyak 20 orang siswa atau 10,36, responden yang memilih bidang karier artistik (artistic) sebanyak 36 orang siswa atau 18,65, responden yang memilih bidang karier sosial (soaial) sebanyak 72 orang siswa atau 37,31, responden yang memilih bidang karier enterpising sebanyak 12 orang siswa atau 6,22\%, dan responden yang memilih bidang karier konvensional (conventional) sebanyak 24 orang siswa atau 12,44\%. Bila nilai frekuensi (f) dan persentase (P) tersebut diranking, maka diperoleh hasil sebagaimana yang diuraikan pada tabel 3 sebagai berikut.

\section{Tabel 3}

\section{Ranking Pilihan Karier Siswa SMA Kelas XI pada Lembaga-Lembaga Pendidikan Islam di Surabaya Berdasarkan Teori John Holland RIASEC $(\mathrm{N}=193)$}

\begin{tabular}{clcc}
\hline No. & \multicolumn{1}{c}{ Bidang Karier } & $\begin{array}{c}\text { Frekuensi } \\
\text { (f) }\end{array}$ & $\begin{array}{c}\text { Persentase } \\
\mathbf{( P )}\end{array}$ \\
\hline 1. & Social & 72 & 37,31 \\
\hline 2. & Artistic & 36 & 18,65 \\
\hline 3. & Realistic & 29 & 15,02 \\
\hline 4. & Conventional & 24 & 12,44 \\
\hline 5. & Investigative & 20 & 10,36 \\
\hline 6. & Enterprising & 12 & 6,22 \\
\hline \multicolumn{2}{r}{ Jumlah } & 193 & 100 \\
\hline
\end{tabular}

Bidang karier sosial (soial) merupakan suatu bidang karier yang paling banyak dipilih responden. Dari 193 responden, 72 orang siswa memilih bidang karier sosial (soial) atau mencapai 37,31\%. Ranking kedua adalah bidang karier artistik (artistid, dipilih 36 responden atau 18,65\%. Ranking ketiga adalah bidang karier realistik (realistid) yang dipilih 29 responden atau 15,02\%. Ranking keempat yaitu bidang karier konvensional (conventional) yang dipilih 24 responden atau 12,44\%. Ranking kelima adalah bidang karier investigatif (investigative) yang dipilih 20 responden atau 10,36\%, sedangkan ranking keenam adalah bidang karier Enterprising yang hanya dipilih oleh 12 responden atau 6,22\%.

Berdasarkan hasil tersebut, atas dasar nilai-nilai Islam sebagian besar responden (37,31\%) memilih bidang karier sosial (soial) yaitu bidang karier yang berhubungan dengan pelayanan kepada manusia (human service) dan memperhatikan kesejahteraan umat manusia. Bentuk aktivitas ini mencakup: memberi informasi, mengajar, melatih, memimpin, dan melayani. Lingkungan kerja pada aspek ini mencakup agen pelayanan, pembimbingan agama, klinik kesehatan, perkantoran, dan fasilitas medis. Jenis pekerjaan/profesi yang termasuk dalam kategori bidang karier Sosial adalah peredam konflik, pemimpin, pengelola, guru/ dosen, ahli pengobatan, psikolog, perawat, konselor, pekerja sosial, dan dokter.

\section{Pembahasan}


Karier adalah istilah yang pada umumnya digunakan untuk menunjuk seberapa jauh kemajuan seseorang dalam melakukan aktivitas profesi atau pekerjaan. Masalah profesi atau pekerjaan di tanah air sampai saat ini masih cukup kompleks, khususnya berkaitan dengan peningkatan jumlah pengangguran ${ }^{12}$ yang berpotensi menimbulkan kerawanan sosial dan berbagai gejolak sosial seperti kriminalitas, premanisme, tindakan kekerasan, dan disparitas sosial. ${ }^{13}$ Untuk mencegah permasalahan tersebut, diperlukan intervensi kepada remaja sebagai generasi penerus bangsa yang diharapkan kelak mampu memberikan kontribusi terhadap kemajuan bangsa dan negara, sehingga bisa memperoleh kebahagiaan di dunia dan di akhirat.

Bantuan dalam pemilihan karier yang diberikan oleh orang-tua, guru, dan tokoh-tokoh agama kepada remaja sebagai generasi penerus bangsa, merupakan sesuatu hal yang lazim terjadi di dalam kehidupan bermasyarakat. Budaya masyarakat komunitas Islam, orang-tua telah menanamkan nilai-nilai agama Islam kepada putra-putrinya yang berlangsung melalui proses interaksi dalam berbagai aktivitas keluarga, begitu juga guru di lembaga-lembaga pendidikan Islam mempunyai peluang yang sama untuk melakukan penanaman nilai-nilai agama Islam kepada anak didiknya melalui proses interaksi sosial yang berlangsung dalam suasana pembelajaran maupun pada berbagai kegiatan keagamaan. Penanaman nilai-nilai agama Islam ini akan membentuk sikap dan perilaku siswa, di antaranya sikap dan perilaku memilih karier sebagai bagian penting dalam kehidupannya.

Pilihan karier (career dhice) merupakan momen penting dalam rentang perkembangan siswa. Menurut Ginzberg, siswa SMA berada di dalam periode realistik yang ditandai terjadinya pengintegrasian berbagai kapasitas dengan minatnya yang terfokus pada pilihan karier. ${ }^{14}$ Sedangkan menurut Super, siswa SMA berada pada periode eksplorasi, di mana mereka menghadapi berbagai pilihan, terutama pilihan yang didasarkan pada kebutuhan untuk memikirkan secara serius tentang kemungkinan memasuki bidang karier tertentu. ${ }^{15}$ Berdasarkan paparan di atas, dapat disimpulkan bahwa pemilihan karier siswa SMA merupakan peristiwa kompleks yang juga dipengaruhi oleh faktor nilai-nilai (values) agama Islam yang diyakininya. Hasil penelitian ini menunjukkan bahwa berdasarkan perspektif nilai-nilai Islam, dari 193 siswa kelas XI SMA pada lembaga-lemaga pendidikan Islam di kota Surabaya yang ditetapkan sebagai responden, sebagian besar yaitu 72 siswa atau 37,31\% memilih bidang karier sosial (soial), 36 siswa atau 18,65\% memilih bidang karier artistik (artistid), 29 siswa atau 15,02\% memilih bidang karier realistik (realistid,24 siswa atau 12,44\% memilih bidang karier konvensional (conventional), 20 siswa atau 10,36\% memilih bidang karier investigatif (investigative), sedangkan hanya 12 siswa atau 6,22\% yang memilih bidang karier enterprising.

Bidang karier sosial sebagai pilihan sebagian besar siswa SMA dalam perspektif nilai-

\footnotetext{
${ }^{12}$ Suwito Ardiyanto, Esens danKdajakan Strateejs (D epartemen Tenaga Kerja dan Transmigrasi: 2007), 12. Tersedia di http:/ / www.nakertrans.go.id.

${ }_{13}$ Hartono, Bimbingan Karier Bebonturan Komputer untuk Siswa SMA, Edisi Petama (Surabaya: University Press UNIPA, 2010), 2.

${ }^{14}$ Vernon G. Z unker, Career Counseling: A pplied Concepts of Life Planning, Sixth Edition (United Kingdom: Brooks/ Cole., 2002), 35.

${ }^{15}$ Richard S. Sharf, ApplyingCareer Deddquent TheorytoCounsding ThirdEdition(Australia: Brooks/ Cole., 2002), 158.
} 
nilai Islam karena bidang karier ini diyakini sebagai sumber aktivitas kerja yang dapat mendatangkan amalan yaitu perbuatan baik yang mendatangkan pahala. ${ }^{16}$ Islam merupakan agama besar sebagai sumber nilai-nilai yang diyakini pemeluknya untuk diamalkan dalam kehidupan bermasyarakat, di antaranya adalah dalam bentuk melaksanakan aktivitas karier sebagai wujud pemenuhan kebutuhan aktualisasi diri seseorang (sdf-atualization). Menurut teori Abraham Maslow bahwa seff-adualization reers to the need for seff-fulfillment-the desire to becomeall that oneis capable of being dadoping to ones fullest petential. ${ }^{17}$ Perwujudan diri sebagai suatu kebutuhan pemenuhan keinginan diri, agar seseorang mampu menjadi sesuatu yang diinginkan dalam upaya pengembangan potensinya secara maksimal. Seseorang yang mampu mewujudkan potensi dirinya dalam aktivitas karier yang dipilihnya berdasarkan nilai-nilai agama Islam yang diyakininya, ia senantiasa akan melakukan perbuatan yang baik sebagai perwujudan dari aktivitas kariernya, sebagaimana firman Allah di dalam surat Al Bayyinah ayat 7 yaitu Imal lackiima aamanuu va’amilush shaalihaati ulaaika humkhainul baniygah, yang artinya sesungguhnya orang-orang yang beriman dan beramal saleh mereka itulah sebaikbaiknya makhluk. ${ }^{18}$

Pilihan karier (career dhice) yang tepat yang didasarkan pada ajaran agama Islam dan potensi diri (seff-ptengy) merupakan hikmah dari Allah. Pandangan ini identik dengan melakukan perbuatan profesi yang didasarkan keahliannya yang berguna dan bermanfaat bagi keselamatan umat manusia adalah perwujudan perbuatan ibadah yaitu perbuatan menjalankan perintah Allah, sebagaimana firman Allah di dalam surat Al Baqarah ayat 269, yaitu Yứtil hikmata may yesyaau wa mayútal hikmata fa qad uutija khairan katsiiraw wa maa yackczakkanu illaa ulumalbaab yang artinya Allah memberikan hikmah kepada siapa yang dikehendakiNya, dan barangsiapa yang diberi hikmah, maka sungguh telah diberi kebajikan yang banyak, dan tidak ada yang dapat mengambil pelajaran melainkan orang-orang yang berakal. Begitu juga surat Al-Baqarah ayat 278 yaitu Yaa ayyuhal ladziima aamanut taqullaha naczanum ma baciyaminarribaainkuntummúminin yang artinya hai orang-orang yang beriman, bertaqwalah kepada Allah dan tinggalkanlah sisa-sisa riba, jika kamu orang-orang yang beriman. ${ }^{19}$

Bidang karier sosial (soial) dalam pendekatan tipologi Holland adalah suatu bidang karier yang berhubungan dengan aktivitas kerja yang berhubungan langsung dengan manusia dan bekerja sama dengan mereka. ${ }^{20}$ Menurut Holland, seseorang yang bertipe sosial (soial) memiliki karakteristik kepribadian yaitu; (1) mempunyai keterampilan yang baik dalam berkomunikasi dan berinteraksi sosial, (2) beratensi terhadap problem-problem sosial, (3) berorientasi pada komunikasi dan pelayanan, dan (3) berminat pada aktivitas-aktivitas bidang pendidikan. Lingkungan profesi bidang ini mencakup; (1) sebagai guru pada lingkungan pendidikan, (2) administrator pendidikan (pemimpin dan pengelola), (3) profesor di perguruan tinggi, (4) pekerja sosial, (5) psikolog, (6) sosiolog, (7) konselor, (8) ahli pengobatan, dan

\footnotetext{
${ }^{16}$ D epartemen Pendidikan dan Kebudayaan, KamusBesarBahasaIndonesia(Jakarta: Balai Pustaka, 1990), 25.

${ }^{17}$ Jerald G reenberg \& Robert A. Baron, Behavior in Organizations Undestanding and ManagingtheHuman Sideof Work (6 $6^{\text {th }}$ ed.) (New Jersey: Prentice-Hall International, Inc., 1997), 146.

${ }^{18}$ Nazri Adlany, Al Quran Tejemahan Indonesa(Jakarta: P.T. Sari Agung, 2004), 1260.

${ }^{19}$ Ibid., 82 dan 85.

${ }^{20}$ Hartono, Bimbingan Kanier Bebantuan Komputer untuk Siswa SMA, Edisi Petama (Surabaya: University Press UNIPA, 2010), 74.
} 
(9) perawat profesional. ${ }^{21}$

Bidang karier selain bidang sosial (social) dalam teori Holland seperti realistik, investigatif, artistik, enterprising, dan konvensional, ternyata responden kurang tertarik untuk memilihnya. Hasil penelitian ini menunjukkan bahwa berdasarkan perspektif nilai-nilai Islam, dari 193 siswa kelas XI SMA pada lembaga-lembaga pendidikan Islam di kota Surabaya yang ditetapkan sebagai responden, 36 siswa atau 18,65\% memilih bidang karier artistik (artistic), 29 siswa atau 15,02\% memilih bidang karier realistik (realistic), 24 siswa atau 12,44\% memilih bidang karier konvensional (conventional), 20 siswa atau 10,36\% memilih bidang karier investigatif (investigative), dan hanya 12 siswa atau 6,22\% yang memilih bidang karier enterprising.

Beberapa alasan sebagai kemungkinan penyebab hal tersebut adalah (1) responden mempersepsikan bahwa bidang karier artistik, realistik, konvensional, investigatif, dan enterprising sebagai suatu bidang karier yang kurang memberikan peluang untuk melakukan dakwah, sehingga mereka menganggap dalam menjalankan karier pada bidang-bidang itu kurang mendapatkan amalan; dan (2) responden menganggap bidang karier tersebut kurang dapat memberikan kemanfaatan sebagai sarana untuk (a) aktualisasi atas potensinya, (b) mengabdikan diri kepada masyarakat, (c) sumber ekonomi/ nafkah keluarga, dan (d) mencapai status sosial dan psikologis yang diinginkan.

\section{Aktualisasi.}

Setiap manusiamemiliki kebutuhan untuk mengaktualisasikan potensinya yaitu berbagai kecerdasan dan keterampilan dalam bidang tertentu. Pada era sekarang, aktualisasi diri (safactualization) dalam bentuk berkarier sudah menjadi kebutuhan setiap individu, termasuk siswa SMA sebagai generasi penerus bangsa. Kebutuhan ini menjadi semakin penting didorong oleh aspek etos kerja yaitu suatu persepsi masyarakat muslim bahwa bekerja sebagai suatu aktivitas yang harus dilakukan dalam kehidupan untuk mewujudkan kesejahteraan pribadi dan keluarganya.

\section{Mengabdikan diri kepada masyarakat.}

Pada hakikatnya berkarier adalah memberikan pelayanan kepada masyarakat luas dalam berbagai profesi, seperti profesi guru, dosen, konselor, dokter, psikolog, psikiater, akuntan, apoteker, pengacara, dan sebagainya. Di negara mana pun, masyarakat pasti membutuhkan pelayanan profesi. Contoh: untuk meningkatkan kualitas kehidupan masyarakat, diperlukan penyelenggaraan pendidikan formal yang berkualitas, di samping pendidikan informal dan nonformal. Pelayanan pendidikan formal yang berkualitas ini diampu oleh para guru dan dosen sebagai pendidik profesional yang dibantu oleh tenaga kependidikan dalam bidangnya. Untuk meningkatkan kualitas kesehatan masyarakat luas, diperlukan pelayanan kesehatan yang berkualitas. Pelayanan ini diampu oleh para dokter dalam berbagai spesialis dan tenaga medis lainnya. Pelayanan-pelayanan profesi ini merupakan wujud pengabdian diri kepada masyarakat. 


\section{Sumber ekonomi/ nafkah keluarga.}

Keluarga sebagai unit sosial yang sangat berpengaruh terhadap kualitas hidup masyarakat. Masyarakat terdiri dari kumpulan berbagai keluarga yang membentuk suatu sistem. Di dalam kehidupan keluarga yang sejahtera, diperlukan aktivitas karier sebagai sumber ekonomi dan nafkah untuk memenuhi berbagai kebutuhan hidup seperti makanan yang bergizi, pakaian, perumahan, dan fasilitas hidup lainnya. Dalam dunia modern saat ini, berkarier sudah menjadi budaya masyarakat muslim. Hal ini tidak hanya dilakukan oleh kaum laki-laki saja, tapi juga oleh kaum perempuan yang disebut sebagai wanita karier. Kehadiran wanita karier, dilihat dari aspek keluarga akan memperkuat ekonomi keluarganya. Semakin kuat ekonomi keluarga juga akan berdampak positif terhadap pembangunan bangsa. D engan demikian jelas bahwa eksistensi karier seseorang juga sebagai sumber ekonomi dan nafkah keluarganya. Sebagaimana firman Allah dalam surat al-A'raaf ayat 10 yaitu (artinya) dan sungguh Kami telah menempatkan kamu di bumi dan Kami jadikan di dalamnya penghidupan bagi kamu, sedikit sekali kamu bersyukur. ${ }^{22}$ Begitu juga firman Allah dalam surat A th Thalaaq ayat 2-3 yaitu (Artinya) barangsiapa bertaqwa kepada Allah, niscaya Dia menjadikan jalan ke luar baginya, dan Dia akan memberikan rezeki kepadanya dengan tiada terkira. D an barangsiapa bertawakal kepada Allah, niscaya D ia mencukupkannya. Sesungguhnya Allah menjadikan ketentuan bagi tiap-tiap sesuatu. ${ }^{23}$

\section{Status sosial dan psikologis.}

Kemajuan suatu karier yang dicapai seseorang akan berdampak pada peningkatan status sosialnya. Di sisi lain, peningkatan status sosial seseorang dapat menimbulkan kepuasan psikologis. Menurut Robbins, banyak penelitian memberikan bukti bahwa kepuasan kerja dapat meningkatkan produktivitas kerja. ${ }^{24}$ Sebagai contoh kebanyakan orang yang puas dalam melakukan pekerjaannya, mereka cenderung menunjukkan perilaku produktif. Gambaran perilaku produktif mencerminkan kemampuan seseorang dalam melakukan inovasi-inovasi yang menghasilkan produk jasa dan barang yang dibutuhkan oleh masyarakat luas.

\section{Kesimpulan.}

Menyimak hasil analisis data, paparan hasil penelitian dan pembahasan, disimpulkan hasil penelitian ini sebagai berikut.

Berdasarkan perspektif nilai-nilai Islam, dari 193 siswa kelas XI SMA pada lembagalemaga pendidikan Islam di kota Surabaya yang ditetapkan sebagai responden, sebagian besar yaitu 72 siswa atau 37,31\% memilih bidang karier sosial (soial), 36 siswa atau 18,65\% memilih bidang karier artistik (artistid, 29 siswa atau 15,02\% memilih bidang karier realistik (realistid, 24 siswa atau 12,44\% memilih bidang karier konvensional (conventional), 20 siswa atau 10,36\% memilih bidang karier investigatif (investigative), sedangkan hanya 12 siswa atau $6,22 \%$ yang memilih bidang karier enterprising.

${ }^{21}$ Vernon G. Z unker, Career Canseling Applied Conepts of Life Planning, Sixth Edition (United Kingdom: Brooks/ Cole., 2002), 61.

${ }^{22}$ Nazri Adlany, Al Quran TejemahanIndonesia(Jakarta: P.T. Sari Agung, 2004), 276.

${ }^{23}$ Ibid., 1139.

${ }^{24}$ Stephen P. Robbins, Organizational Behavior: Concepts Controwersies A pplications ( $7^{\text {th }}$ ed.). (New Jersey: Prentice Hall, Inc., 1996), 170. 


\section{Rekomendasi.}

Sehubungan dengan hasil penelitian ini, peneliti merekomendasikan beberapa hal sebagai berikut.

1. Pilihan karier (career haic) merupakan aspek penting dalam kehidupan masyarakat muslim yang dipengaruhi oleh nilai-nilai agama Islam. Terkait dengan hal ini, peran orang-tua, guru, dan tokoh-tokoh agama Islam sangat urgen dalam menanamkan nilai-nilai ajaran agama Islam kepada anak didiknya (para siswa SMA) sebagai generasi penerus bangsa. Di SMA, penanaman nilai-nilai agama Islam bisa dilakukan melalui penciptaan suasana pembelajaran yang kondusif dan proses interaksi antara guru dengan para siswa sebagai amalan atas implementasi ajaran agama Islam, pembelajaran mata pelajaran pendidikan agama Islam, berbagai kegiatan keagamaan serta keteladanan guru.

2. Guru bimbingan dan konseling (konselor sekolah) pada SMA di lembaga-lembaga pendidikan Islam, lazimnya memberikan pelayanan bimbingan karier kepada para siswa (konseli) melalui berbagai pendekatan individual maupun kelompok yang sesuai dengan kebutuhan siswa (konseli). Pendekatan individual dalam bentuk pelayanan konseling karier individual, sedangkan pendekatan kelompok dalam bentuk (a) pelayanan konseling kelompok, (b) pelayanan bimbingan kelompok, (c) pelayanan informasi, (d) pelayanan orientasi, dan (e) pelayanan penempatan dan penyaluran.

3. Untuk dapat memberikan pelayanan bimbingan karier kepada para siswa (konseli) secara memadai yang sesuai dengan kebutuhan mereka, guru bimbingan dan konseling (konselor sekolah) perlu mengembangkan materi bimbingan karier yang berbasis nilai-nilai Islam. Nilai-nilai (values) Islam merupakan suatu keyakinan mengenai cara bertingkah laku dan tujuan akhir yang diinginkan individu, yang digunakan sebagai prinsip atau standar dalam hidupnya yang bersumber dari Alquran dan Alhadis.

4. Untuk dapat mewujudkan kualitas pelayanan bimbingan karier yang baik, perlu dilakukan pengembangan jejaring atau sistem kerja sama antara guru bimbingan dan konseling (konselor sekolah) dengan para guru mata pelajaran dan staf sekolah lainnya dalam rangka implementasi pelayanan bimbingan karier kepada para siswa (konseli).

5. Temuan penelitian ini juga berimplikasi pada sistem rekrutmen tenaga konselor sekolah (guru bimbingan dan konseling) SMA pada lembaga-lembaga pendidikan Islam, lazimnya dilakukan untuk mendapatkan tenaga konselor profesional dalam arti mampu menguasai kompetensi konselor yaitu (a) mampu mengenal secara mendalam tentang peserta didik (konseli) yang dilayani, (b) mampu menguasai kerangka teoritik bimbingan dan konseling, (c) mampu memberikan pelayanan bimbingan dan konseling yang memandirikan peserta didik (konseli), (d) mampu mengembangkan diri dan meningkatkan profesionalitas secara berkelanjutan, dan (e) mampu memahami aqidah Islam dan menjadikan aqidah Islamiyah sebagai standar hidupnya.

6. Untuk meningkatkan kompetensi guru bimbingan dan konseling (konselor sekolah) di lingkungan SMA pada lembaga-lembaga Islam, perlu dilakukan berbagai kegiatan pendidikan dan pelatihan yang memadai serta mengikut sertakan mereka pada berbagai kegiatan peningkatan profesionalitas seperti penelitian tindakan kelas dalam bimbingan dan konseling, seminar, workshop, dan studi lanjut. 


\section{Daftar Rujukan}

Admin. 2010. Implementasi Nilai-Nilai Isam dalam Dunia Pendidikan (O nline), (http:/ / www.wahdah-tarakan.org, diakses tanggal 18 Februari 2010 pukul 18.45 WIB).

Berry, J., W.; Poortinga, Y., H.; Seegal, M., H., and D osen, P., R. 1992. Cross-Cultural Psyddogy: Rearch and A pdications Canada: Cambridge University Press.

D epartemen Pendidikan dan Kebudayaan. 1990. Kams Besar Bahasa Indonesia Jakarta: Balai Pustaka.

Ferry, N. M. 2006. Factors Influencing Career Choices of Adolescents and Young Adults in Rural Pennsylvania. Jamal of Extension, 44, 3-16.

Gall, M.D., Gall, J.P. \& Borg, W.R. 2003. Edurational Reserds: An Introduction (7 $7^{\text {th }}$ ed.). New York: Pearson Education, Inc.

Greenberg, J. \& Baron, R. 1997. Behavior in Organizations: Undastanding and Managing the Human Side of Work ( $6^{\text {th }}$ ed.). New Jersey: Prentice-Hall International, Inc.

Hartono. 2010. Bimbingan Kavier Bedbantuan Komputer Untuk Sisma SMA. Surabaya: University Press UNIPA Surabaya.

Isamic Reigian (Online), http:/ / www.cristalinks.com, diakses tanggal 28 Maret 2010 pukul 20.00 WIB.

Miller, M.J. \& Miller, T.A. 2005. Theoretical Application of Holland's Theory to Individual Decision-Making Styles: Implications for Career Counselors. Jaumal of Employmet Canseling 42, 1, 20-28.

Mohamed Nimer. 2005. An Educator's Guideto IstamicReigias Pradices (O nline). Council on American-Islamic Relations (CAIR), http:/ / www.cair.com, diakses tanggal 28 Maret 2010 pukul 21.00 WIB. p.6

Myburgh, JE. 2005. An Empirical Analysis of Career Choice Factors that Influence firstyear Accounting Students at the University of Pretoria: A Cross-racial Study. Medtary Accuntangy Rearch, 13, 35-48.

Nafiisah M. Ridlwan. 2009. Sikap Hidpp Seorang Musimahr Komitmennya Tehadap Nilai-Nilai Islam(Online), (http:/ / www.angelfire.com, diakses tanggal 18 Februari 2010 pukul 18.20 WIB.

Nazri Adlany, dkk. 2004. Al Quran Tejemahan Indonesia Jakarta: P.T. Sari Agung.

NIU Career Service. 2009. CareerInterestAreas(Online). (http:/ / www.niu.edu/ careerservice, diakses tanggal 19 Maret 2009 pukul 09.30 WIB). p.1-2.

O zbilgin, M., Kusku, F., and Erdogmus, N. 2004. Explaining Influenes on Carer Chice in Comparative Pespeetive Intemational Progams Visiting Fellow Working papers http:/ / digitalcommons.ilr.cornell.edu/ intlvf/ 1, diakses tanggal 10 Desember 2007 pukul 19.15 WIB.

Robbins, S. P. 1996. Onganizational Behavior: Conepts, Controwesies, Applications (7th ed.). New Jersey: Prentice Hall, Inc.

Sharf, R., S. 2002. Applying Career Deudqumet Theary to Cansding(Third Edition). Australia: Brooks/ Cole.

Suwito Ardiyanto. 2007. Esensi dan Kebijakan Strategis. Departemen Tenaga Keja dan Transmigasi, (O nline), (http:/ / www.nakertrans.go.id, diakses tanggal 3 Mei 2007 pukul 
10.23 WIB).

Triandis, H., C. 1994. Cultureand Sodial Behaviar. New York: McG raw-Hill, Inc.

Watson, M.B., Stead G. B., and De Jager, A. C. 2005. The Career D evelopment of Black and White South African University Students. Intemational Joumal for the Advanement of Counsiing 18, 39-47.

Webster. 1998. Unabridged Didionary (USA). New York: MICRA.

Wikipedia The Fræe Engdqpedia (2008). http:/ / wikimediafoundation.org, diakses tanggal 3 Februari 2008 pukul 12.58 Wib.

Z unker, V., G. 2002. Career Counsding Applied Concepts of LifePlanning Sixth Edition United Kingdom: Brooks/ Cole. 